\title{
Sedimentation mechanism of Cd in Jiaozhou Bay waters Dongfang Yang ${ }^{1,2,3, a}$, Xiancheng $\mathrm{Qu}^{1}$, Yu Chen ${ }^{2}$, Shubo Fang ${ }^{1,2}$ and Yinjiang Zhang ${ }^{1, b, c}$ \\ ${ }^{1}$ China College of Life Science, Shanghai Ocean University, Shanghai, 201306, China \\ ${ }^{2}$ College of Life Science, Shanghai Ocean University, Shanghai, 201306, China \\ ${ }^{3}$ North China Sea Environmental Monitoring Center, SOA, Qingdao 266033, China.

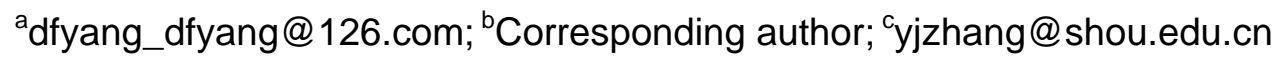

Keywords: Cd, Distribution, Water quality, Sedimentation mechanism, Jiaozhou Bay.

\begin{abstract}
This paper analyzed the content, distribution, and sedimentation mechanism of Cd in Jiaozhou Bay based on investigation data in April, July and October 1985. Results showed that the Cd contents in surface waters ranged from $0.04-0.32 \mu \mathrm{g} \mathrm{L}^{-1}$, and were meeting Grade I for Cd (1.00 $\mu \mathrm{g} \mathrm{L}^{-1}$ ) in Chinese Sea Water Quality Standard, indicated that Jiaozhou Bay and the open sea had not been polluted by $\mathrm{Cd}$ in 1985 . High $\mathrm{Cd}$ sedimentation locations were occurring in different regions due to $\mathrm{Cd}$ contents were different in surface waters. In April and October, high $\mathrm{Cd}$ sedimentation location was in the open sea in where marine current was the major source; while in July, high Cd sedimentation location was in the bay mouth in where stream flow was the major source. In generally, the spatial-temporal of sedimentation features of Cd were determined by pollution sources and the vertical water's effect.
\end{abstract}

\section{Introduction}

Cd is not essential elements for human, but one of the most critical heavy metals which had been causing serious environmental issues in mangy countries and regions. A large amount of Cd-contained waste water and gas were discharged into waters along with the rapid development economic [1-2], and was finally discharged into the marine environment [3-7]. Hence, understanding the transformation and fate of $\mathrm{Cd}$ in marine bay is essential to marine environmental protection. Jiaozhou Bay is a semi-closed bay located in south of Shandong Peninsula, eastern Chin. This paper analyzed the content, distribution, and sedimentation mechanism of Cd in Jiaozhou Bay and the open sea, and to provide scientific basis for the research on the source, pollution level and transfer process of Cd in sea waters.

\section{Material and method}

Jiaozhou Bay $\left(35^{\circ} 55^{\prime}-36^{\circ} 18^{\prime} \mathrm{N}, 120^{\circ} 04^{\prime}-120^{\circ} 23^{\prime} \mathrm{E}\right)$ is located in the south of Shandong Province, eastern China (Fig. 1). It is a semi-closed bay with the total area, average water depth and bay mouth width of $446 \mathrm{~km}^{2}, 7 \mathrm{~m}$ and $3 \mathrm{~km}$, respectively, and is connect to Yellow Sea in the south. There are more than ten inflow rivers (e.g., Haibo Rriver, Licun Rriver, Dagu Rriver, and Loushan Rriver), most of which have seasonal features [8,9]. The data was provided by North China Sea Environmental Monitoring Center. The survey was conducted in April, July and October 1985. Bottom water samples in three stations (i.e. 2031, 2032 and 2033) were collected and measured followed by National Specification for Marine Monitoring [10]. 


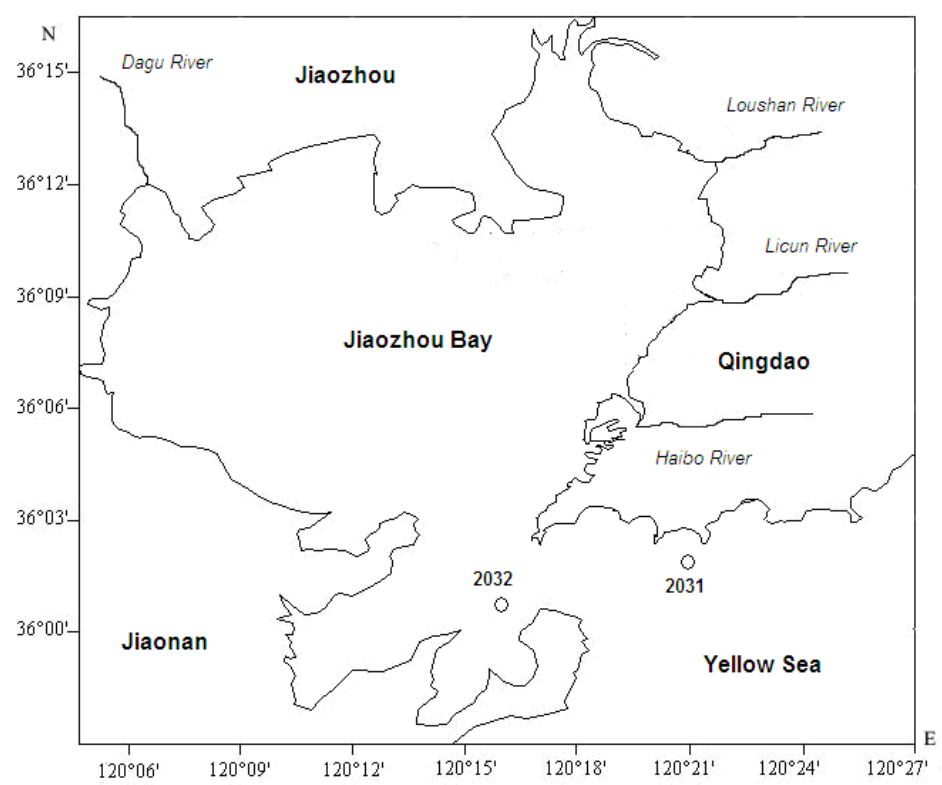

Fig. 1 Geographic location and sampling sites in Jiaozhou Bay

\section{Results and discussion}

Content and water quality of Cd. The contents of Cd in April, July and October in 1985 in surface waters in Jiaozhou Bay and the open sea were $0.19-0.32 \mu \mathrm{g} \mathrm{L}^{-1}, 0.11-0.17 \mu \mathrm{g} \mathrm{L} \mathrm{L}^{-1}$ and 0.04-0.17 $\mu \mathrm{g} \mathrm{L}^{-1}$, respectively (Table 1). In comparison with Grade I (1.00 $\mu \mathrm{g} \mathrm{L}^{-1}$ ) of National Sea Water Quality Standard (GB 3097-1997) for Cd, the Cd contents were very low. Once Cd was discharged to the surface waters, it would be transported through the water body, and then to the sea bottom. For the whole year, Cd contents were $0.04-0.32 \mu \mathrm{g} \mathrm{L} \mathrm{L}^{-1}$ by mean of vertical water's effect, indicated that Jiaozhou Bay and the open sea had not been by Cd in 1985.

Table 1 Cd content and water quality in Jiaozhou bay in April, July and October 1985

\begin{tabular}{|c|c|c|c|}
\hline Month & April & July & October \\
\hline Content $/ \mu \mathrm{g} \mathrm{L}^{-1}$ & $0.19-0.32$ & $0.11-0.17$ & $0.04-0.17$ \\
\hline Grade & $\mathrm{I}$ & $\mathrm{I}$ & $\mathrm{I}$ \\
\hline
\end{tabular}

Distribution and sedimentation mechanism of Cd. The three sampling Sites of 2031, 2032 and 2033 were located in the open sea, the bay mouth and the inside of the bay mouth, respectively. In April, there was a high value occurred in Site 2031 in open waters in the east, and there were a series of parallel lines, which were decreasing from the open waters $\left(0.32 \mu \mathrm{g} \mathrm{L}^{-1}\right)$ to the bay mouth in the west $\left(0.19 \mu \mathrm{g} \mathrm{L}^{-1}\right)$ (Fig. 2). In July, high value region occurred in Site 2032 in the bay mouth, and there were a series of parallel lines, which were decreasing from the bay mouth $\left(0.17 \mu \mathrm{g} \mathrm{L}^{-1}\right)$ to the open waters $\left(0.12 \mu \mathrm{g} \mathrm{L}^{-1}\right)$ (Fig. 3). In October, high value region occurred in Site 2031 in coastal waters in the open sea, and there were a series of parallel lines, which were decreasing from the open sea $\left(0.17 \mu \mathrm{g} \mathrm{L}^{-1}\right)$ to the bay mouth $\left(0.04 \mu \mathrm{g} \mathrm{L}^{-1}\right)$ (Fig. 4). The different distributions of Cd indicated that there might be different pollution sources in different seasons.

Sedimentation process of $\mathbf{C d}$. The contents of the substances were decreasing contentiously by means of water exchange from the bay and the open sea via the bay mouth [12]. In April, Cd contents were $0.19-0.32 \mu \mathrm{g} \mathrm{L}^{-1}$, and were increasing from the bay mouth to the open sea, indicating that high sedimentation location was in the open waters, yet low sedimentation rate region was in the bay mouth. In July, Cd contents were $0.11-0.17 \mu \mathrm{g} \mathrm{L}^{-1}$, and were increasing from the bay mouth to the open sea and the inside of the bay, indicating that high sedimentation location was in the bay mouth, yet low sedimentation rate region was in the open sea and inside the bay. In October, Cd contents were 0.04-0.17 $\mu \mathrm{g} \mathrm{L}^{-1}$, and were increasing from the bay mouth to the open sea, indicating that high sedimentation location was in the open waters, yet low sedimentation rate region was in 
the bay mouth. In generally, high sedimentation locations were occurring in different positions in different seasons. High sedimentation location was the open sea in April and July, while for October were in the bay mouth.

Sedimentation mechanism of Cd. Stream flow was only one major source of Cd in Jiaozhou Bay, and the source strength was 0.21-0.44 $\mu \mathrm{g} \mathrm{L}^{-1}$. In April and October, the Cd contents in surface waters were as high as $0.39-0.44 \mu \mathrm{g} \mathrm{L}^{-1}$, and were reduced to $0.17-0.32 \mu \mathrm{g} \mathrm{L}^{-1}$ in bottom waters after the transport through the water body. By means of vertical water's effect [11], high Cd contents would be transported far away along with the flow direction, leading to the high sedimentation location in the open sea. In July, the Cd contents in surface waters were as low as $0.21 \mu \mathrm{g} \mathrm{L}^{-1}$, and were reduced to $0.17 \mu \mathrm{g} \mathrm{L}^{-1}$ in bottom waters after the transport through the water body. By means of vertical water's effect [11], low Cd contents would not be transported far away along with the flow direction, leading to the high sedimentation location in the bay mouth.

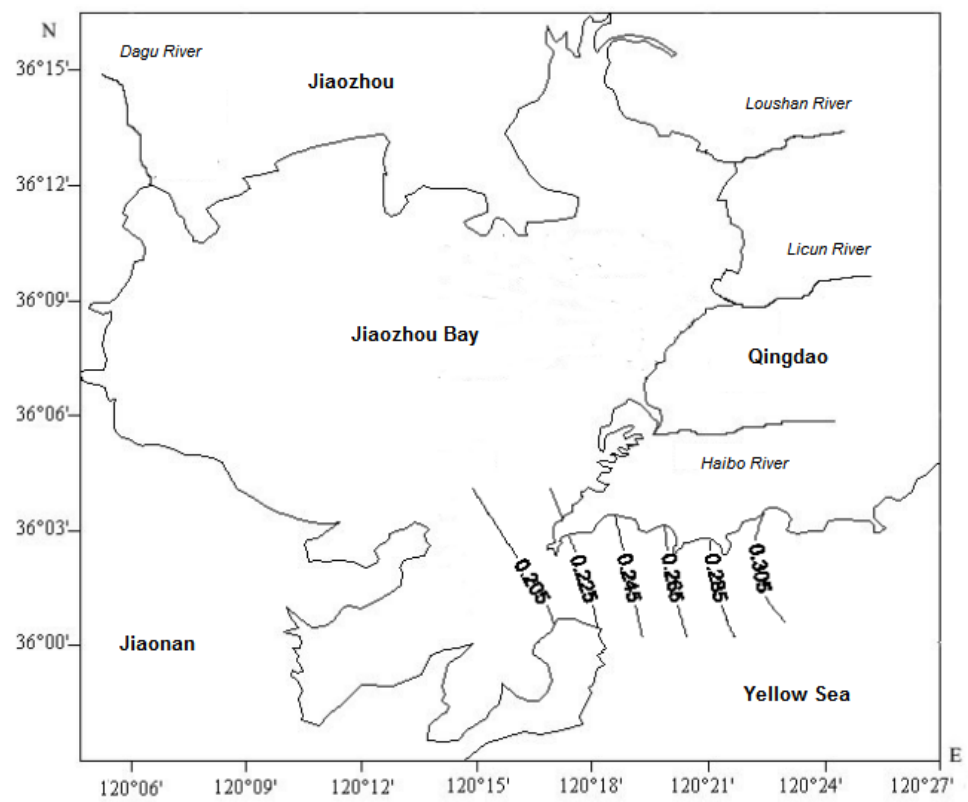

Fig. 2 Distributions of Cd in surface waters in Jiaozhou Bay in April 1985

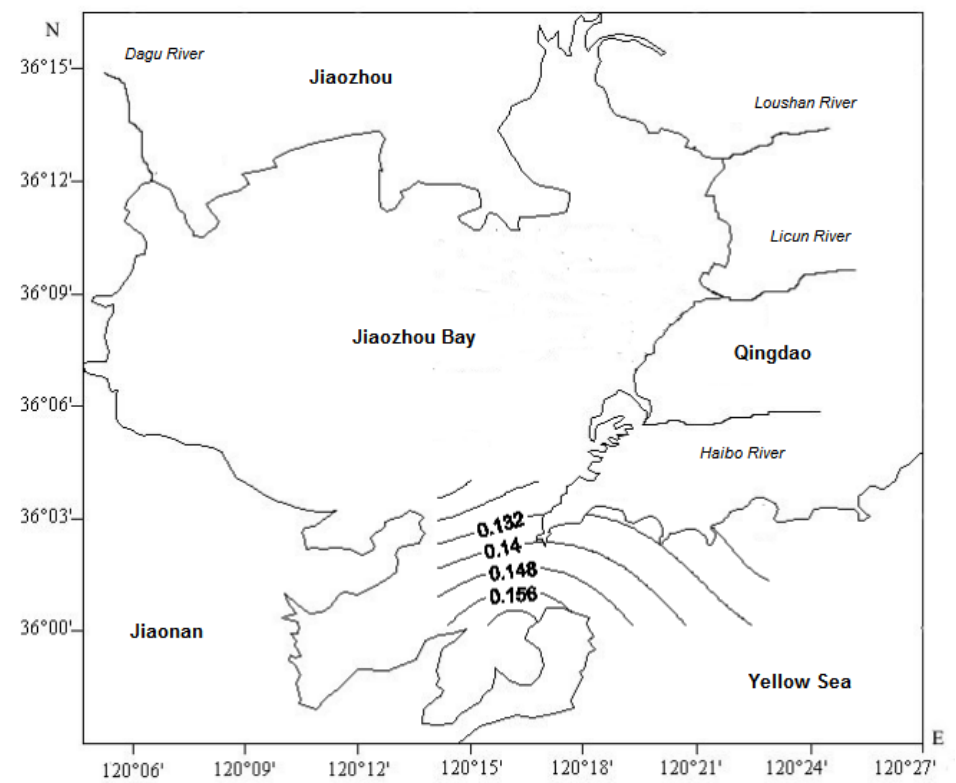

Fig. 3 Distributions of Cd in surface waters in Jiaozhou Bay in July 1985 


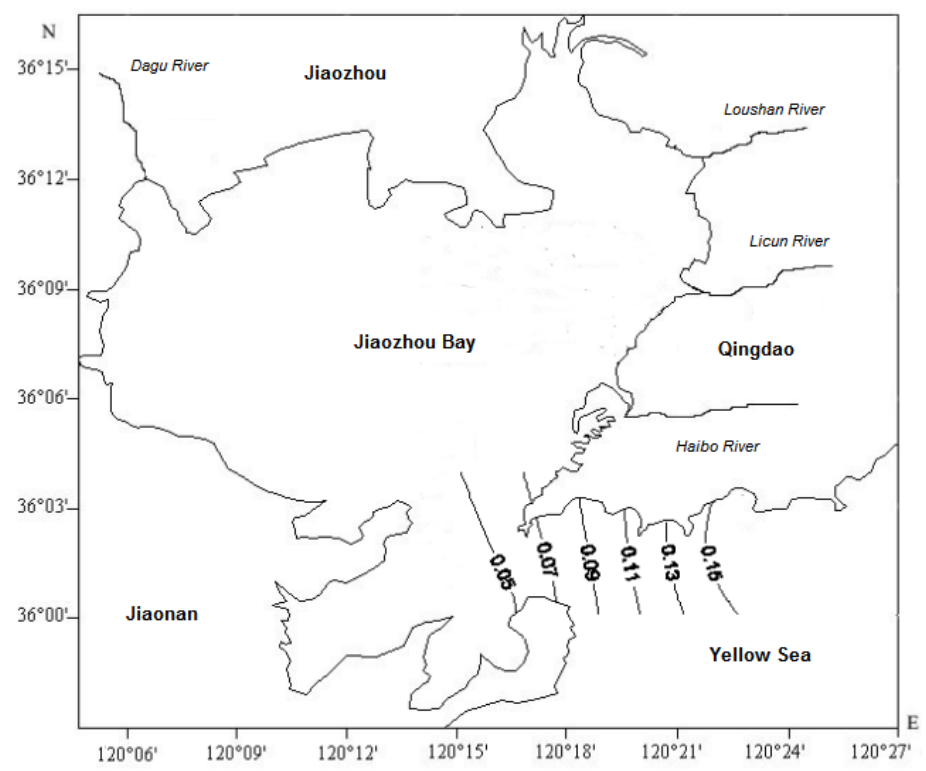

Fig. 4 Distributions of Cd in surface waters in Jiaozhou Bay in October 1985

\section{Conclusions}

The Cd contents in the whole year were $0.04-0.32 \mu \mathrm{g} \mathrm{L} \mathrm{L}^{-1}$ by mean of vertical water's effect, indicated that Jiaozhou Bay and the open sea had not been by Cd in 1985. High sedimentation locations were occurring in different positions in different seasons. High sedimentation location was the open sea in April and July, while for October were in the bay mouth. Stream flow was only one major source of Cd in Jiaozhou Bay. By means of vertical water's effect, high Cd contents would be transported far away along with the flow direction, leading to the high sedimentation location in the open sea, while low Cd contents would not be transported far away along with the flow direction, leading to the high sedimentation location in the bay mouth.

\section{Acknowledgement}

This research was sponsored by Doctoral Degree Construction Library of Guizhou Nationalities University, Education Ministry's New Century Excellent Talents Supporting Plan (NCET-12-0659), the China National Natural Science Foundation (31560107) and Research Projects of Guizhou Nationalities University ([2014]02), Research Projects of Guizhou Province Ministry of Education (KY [2014] 266), Research Projects of Guizhou Province Ministry of Science and Technology (LH [2014] 7376).

\section{References}

[1] Yang DF and Miao ZQ: Marine Bay Ecology (I): Beijing, Ocean Precess, (2010), p. 1-320. (in Chinese)

[2] Yang DF and Miao ZQ: Marine Bay Ecology (II): Beijing, Ocean Precess, (2010), p. 1-320. (in Chinese)

[3] Yang DF, Chen Y, Wang H, et al.: Coastal Engineering, Vol. 29 (2010), p. 73-82.

[4] Yang DF, Chen Y, Liu CX, et al.: Coastal Engineering, Vol. 32(2013), p. 68-78.

[5] Yang DF, Zhu SX, Wu YF, et al.: Applied Mechanics and Materials, Vols.644-650 (2014), p. 5325-5328.

[6] Yang DF, Wang FY, Wu YF, et al.: Applied Mechanics and Materials, Vols.644-650 (2014), p. 5329-5312. 
[7] Yang DF. Chen Y, Gao ZH, et al.: Proceedings of the 2015 international symposium on computers and informatics, (2015), p. 2667-2674.

[8] Yang DF, Chen Y, Gao ZH, et al.: Chinese Journal of Oceanology Limnology, Vol. 23(2005): 72-90.

[9] Yang DF, Wang F, Gao ZH, et al.: Maine Science, Vol. 28(2004): 71-74.

[10]State Ocean Administration. The specification for marine monitoring ( HY003.4-91): Beijing, Ocean Precess, (1991): 205-282. (in Chinese)

[11] Yang DF, Wang FY, He HZ, et al.: Proceedings of the 2015 international symposium on computers and informatics, (2015): 2655-2660.

[12]Yang DF, Miao ZQ, Xu HZ, et al.: Marine Environmental Science, Vol. 32 (2013):373-380. 